\title{
Introduction: The Printing Press as an Agent of Power
}

\author{
Helmer Helmers, Nina Lamal and Jamie Cumby
}

On the frontispiece of Prosper Marchand's 1740 history of the printing press, written at the tercentenary of its presumed invention, the press is an emblem of Enlightenment. Descending from the heavens, it spreads its light and is welcomed by Minerva and Mercury, the gods of wisdom and dissemination. In all its Enlightenment idealism, Marchand's emblem is at the heart of a longstanding, and to some extent still persistent discourse: that the invention of the printing press was an emancipating power, a bringer of light. ${ }^{1}$ It is therefore no coincidence that the second edition of Elizabeth Eisenstein's seminal work Printing Revolution in Early Modern Europe used this captivating engraving as a frontispiece. ${ }^{2}$ If the invention of the printing press was, in Eisenstein's famous phrase, an agent of change, that change has been perceived to be a largely positive, modernising force by many scholars writing long after Marchand. ${ }^{3}$ Print's wide reach and persistence over time was conducive to standardisation, to cultural memory and to cross-cultural interchange on a previously unimaginable scale. ${ }^{4}$ It spurred the spread of literacy, allowed ordinary people to access different sources of information and gave permanence to radical ideas challenging conceived wisdom. On such an account, the new technology

1 For a brief discussion of the 1740 print and an overview of how print became synonymous with liberal progress and the modern nation state see Trish Loughran, 'Books in the nation', in Leslie Howsam (ed.), The Cambridge Companion to the History of the Book (Cambridge: Cambridge University Press, 2014), pp. 36-39.

2 Elizabeth Eisenstein, The Printing Revolution in Early Modern Europe (Cambridge: Cambridge University Press, 1983), p. iii.

3 Elizabeth Eisenstein, The Printing Press as an Agent of Change. Communications and Cultural Transformations in Early Modern Europe (Cambridge: Cambridge University Press, 1979). See also: Sabrina Alcorn Baron, Eric N. Lindquist and Eleanor F. Shevlin (eds.), Agent of Change: Print Culture Studies After Elizabeth L. Eisenstein (Amherst: University of Massachusetts Press, 2007). On bible reading, e.g. Natalie Zemon Davis, 'Printing and the People', in her Society and Culture in Early Modern France. Eight Essays by Natalie Zemon Davis (Stanford: Stanford University Press, 1965), pp. 189-226.

4 For Eisenstein the persistence of print was an important argument, see Eisenstein, The Printing Press as an Agent of Change, pp. 113-126. For the debate on these issues see the discussion between Eisenstein and Johns, 'How Revolutionary was the Print Revolution?', American Historical Review, 107:1 (2002), pp. 84-128.

(C) HELMER HELMERS, NINA LAMAL AND JAMIE CUMBY, 2021 | DOI:10.1163/9789004448896_002 


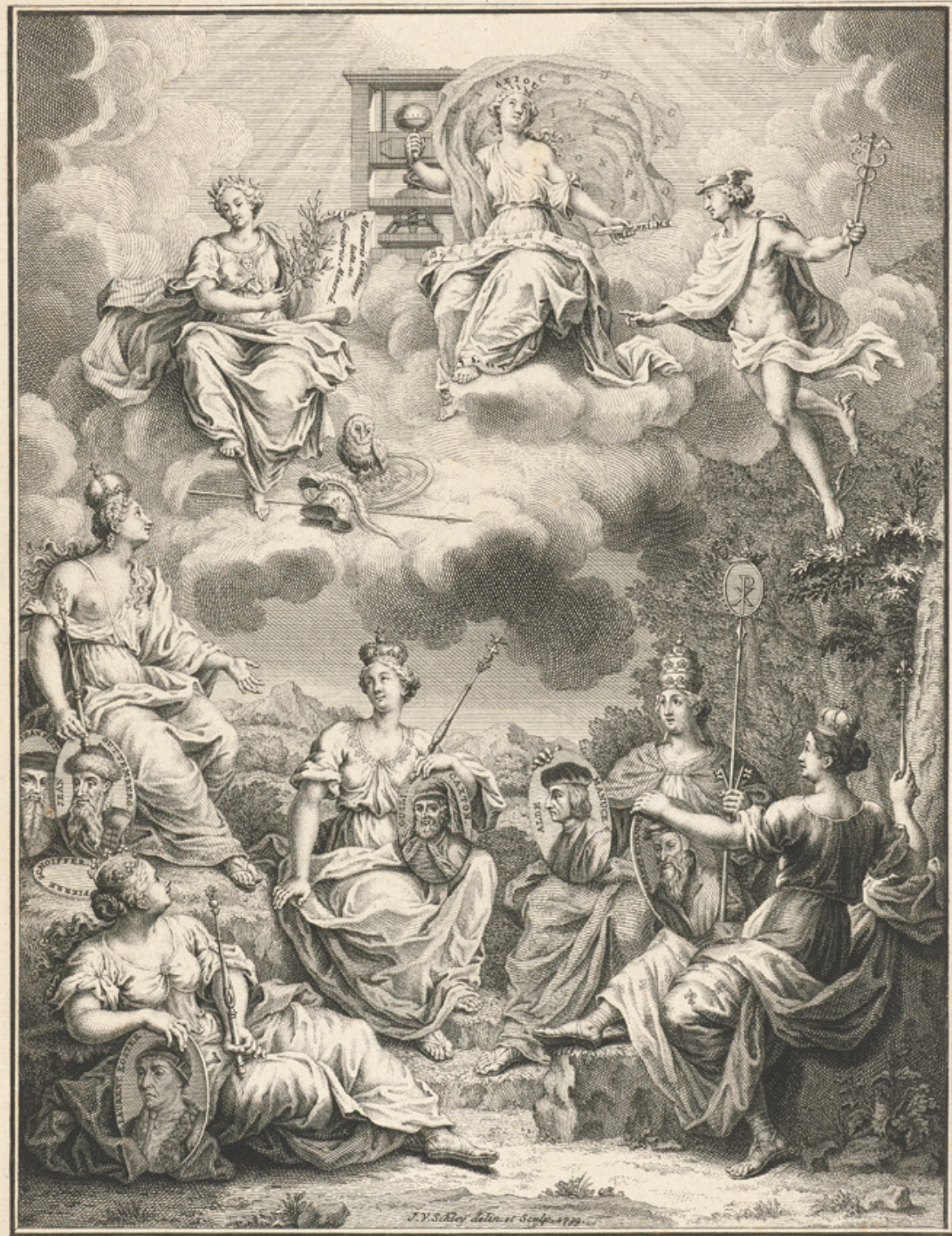

L'IMPRTMERTE, descendant des Gieux, est accondie par Minerve at Mercure à $\ell$ 'Allemagne, qui la prisente à la Hollande, l'Angleterre, l'Italie, \& la France, les quatre prémierres SVations ches les quelles ce bel. lort fut adoptés

FIGURE 0.1 Jacob van der Schley, 'Allegory of the art of printing'. Frontispiece for Prosper Marchand, Histoire de l'origine et des prémiers progrès de l'imprimerie (The Hague: Pieter Paupie, 1740) RIJKSMUSEUM, AMSTERDAM RP-P-OB-67.367 
brought social and intellectual changes that could confidently be labelled as enlightening progress.

The medium of print has also been credited with the power to effect profound political and religious change. Indeed, some of the most spectacular uses of print in its early history belong to reformers challenging power. The Protestant movement by Martin Luther used print to help build a transnational and multilingual movement opposing the authority of the Catholic Church and Catholic rulers throughout Europe. ${ }^{5}$ In the realm of politics, rebels against monarchical authority, such as those in the sixteenth-century Low Countries, who mustered the power of print to convince both domestic and foreign audiences of the righteousness of their cause against Philip II. ${ }^{6}$ Print's fixity and adaptability made it a tool of Enlightenment philosophers, whose work circulated and thrived through clandestine distribution networks and falsified imprints in areas where it was formally banned. ${ }^{7}$ Lastly, the newspaper publishers and news writers who purportedly broke the arcana of government helped to create the conditions for public debates on politics. ${ }^{8}$ Such associations, too, fitted a master narrative of modernisation, in which the medium itself

5 The literature on the Reformation and print is vast, see amongst others Bernd Moeller, 'Stadt und Buch. Bemerkungen zur Struktur der reformatorischen Bewegung in Deutschland', in Bernd Moeller and Johannes Schilling (eds.), Die Reformation und das Mittelalter (Göttingen: Vandenhoeck, 1991), pp. 111-124; Thomas Kaufmann, 'Ohne Buchdruck keine Reformation?', in Stefan Oehmig (ed.), Buchdruck und Buchkultur im Wittenberg der Reformationszeit (Leipzig: Evangelischer Verlagsanstalts, 2015), pp. 13-34 and Andrew Pettegree, Brand Luther. 1517, Printing, and the Making of the Reformation (London: Penguin Press, 2016).

6 On the Dutch Revolt: Paul Geurts, De Nederlandse Opstand in de pamfletten, 1566-1584 (Utrecht: HES, 1984); Daniel Horst, De Opstand in zwart-wit: propagandaprenten uit de Nederlandse Opstand (1566-1584) (Zutphen: Walburg Pers, 2003); Christi M. Klinkert, Nassau in het nieuws. Nieuwsprenten van Maurits van Nassaus militaire ondernemingen uit de periode 1590-1600 (Zutphen: Walburg Pers, 2005); Monica Stensland, Habsburg Communication in the Dutch Revolt (Amsterdam: Amsterdam University Press, 2012); On the English Revolution, which was also premised on a lively print culture, see Jason Peacey, Print and Public Politics in the English Revolution (Cambridge: Cambridge University Press, 2013).

7 Robert Darnton, Forbidden Best Sellers of Pre-Revolutionary France (New York: W.W. Norton, 1995). On Darnton as a 'mythmaker' of the Enlightenment as a progressive force see Simon Burrows, The French Book Trade in Enlightenment Europe II. Enlightenment Bestsellers (London: Bloomsbury, 2018), pp. 10-15.

8 The traditional case presented in Jürgen Habermas, T. Burger with the assistance of F. Lawrence (trans.), The Structural Transformation of the Public Sphere. An Inquiry into a Category of Bourgeois Society (Cambridge MA.: Polity Press, 1989). For a good overview of the debate see Andreas Gestrich, 'The Public Sphere and the Habermas debate', German History, 24:3 (2006), pp. 413-430. 
challenged the status quo of the Ancien Régime. ${ }^{9}$ This narrative gained much traction in the twentieth century. Popular culture and various news media have adopted it with gusto, and it survives, for instance, in The Washington Post's tagline, "Democracy Dies in Darkness". ${ }^{10}$ The implicit light, for The Washington Post, is again the published word, which counters the efforts of more authoritarian forces.

Stressing 'the dissident potential of printing' is, however, misleading. As David Adams and Adrian Armstrong have put it, emphasizing print's power to bring about societal change risks creating a distorted picture of its impact, and fails to recognise 'the interplay between media technologies and social control."1 In the past decades, undoubtedly influenced by contemporary experience, historians have become more sensitive to the less enlightening aspects of print in its early modern coming-of-age period. In particular, book historical scholarship of the early modern period has provided ample reason to dim the shining light of Marchand's and Eisenstein's techno-optimism. In various ways, recent work on both early modern European print culture as well as more global book historical research, suggests an intimate rather than adversarial relationship between printing technology and established authority. ${ }^{12}$ Print could become a tool for authorities just as easily as it could be used to challenge them, and actors within the print industry often cultivated a friendly

$9 \quad$ See for a recent example Thomas Munck, Conflict and Enlightenment. Print and Political Culture in Europe, 1635-1795 (Cambridge: Cambridge University Press, 2019).

10 The Washington Post website displayed the new slogan before it appeared in print: $<$ https://www.washingtonpost.com>, visible since 22 February 2017, last accessed 10 June 2020.

11 Adrian Armstrong and David Adams, 'Introduction', in Armstrong and Adam (eds.), Print and Power in France and England, 1500-1800 (Aldershot: Ashgate, 2006), p. 8. The striking difference between their volume and Roger Chartier's 1989 volume on the uses of print underlines the change in focus: Roger Chartier (ed.), The Culture of Print. Power and the Uses of Print in Early Modern Europe (Oxford: Polity Press, 1989).

12 For a more comparative global approach see: Hilde de Weerdt and Julius Morche (eds.), Political Communication in the Medieval World 800-1600 (Amsterdam: Amsterdam University Press, forthcoming); On early modern China: Kai-Wing Chow, Publishing, Culture, and Power in Early Modern China (Stanford: Stanford University Press, 2004) and Cynthia J. Brokaw and Kai-Wing Chow (eds.), Printing and Book Culture in Late Imperial China (Los Angeles: University of California Press, 2005); for seventeenth-century Japan see Mary Elizabeth Berry,Japan in Print: Information and Nation in the Early Modern Period (Los Angeles: University of California Press, 20o6). On printing in the Ottoman Empire: Dana Sajdi, "Print and its Discontents. A Case for Pre-Print Journalism and Other Sundry Print Matters", The Translator, 15:1 (2009), pp. 105-138 and Kathryn A. Schwartz, 'Did Ottoman Sultans Ban Print?', Book History, 2o (2017), pp. 1-39. Also see Sebouh D. Aslanian, 'Port cities and Printers. Reflections on Early Modern Global Armenian Print Culture', Book History, 17 (2014), pp. 51-93. For Europe see the cases discussed below. 
relationship with existing institutions. Overwhelmingly, as we will further illustrate below, this growing body of work on government patronage, propaganda, censorship, as well as the print economy suggests that early modern print was an agent of power at least as much it was as an agent of change. Yet to make sense of the complex interplay between authority, subversion and print is, in the words of Cyndia Susan Clegg, still 'the challenge of book history'.13 This volume takes up that challenge.

While the theme of print and power in early modern Europe is vast, and could and indeed will fill many more books, our broad aim is to redress the notion that print was an agent of modernising change by uniting and building on key strands in recent scholarship. The contributions collected here reflect on how authorities in various places in Europe have shaped the history of print rather than the other way around. From accounts of governmental print commissions to the complex interplay between printers and their individual, elite patrons, to the conscientious use of print to establish and reinforce orthodoxy, these essays construct a coherent story of print as an extension of established power. Only when we realize the full extent to which print was instrumental to authorities and the rise of strong bureaucracies, and map the ways in which it was used by them to influence the minds and bodies of the broader public, can we arrive at a more balanced picture of the relationship between print and power than what the popular and theoretical grand narratives have on offer.

\section{Studying Print and Power}

To study the relationship between print and power in early modern Europe in a meaningful way, we first need to abandon any notion of a fundamental opposition between print and authority. While it might be tempting to adopt an antagonistic model in which the authorities represent control and the market of print represents freedom of expression, research has complicated this model beyond repair. The recent historiography of censorship, for example, which by its nature is prone to highlight the opposition, shows a much more complex picture, offering many examples of print acting in the service of power. The Indexes of prohibited books promulgated throughout the early modern period were printed documents, too, and the demands of religious orthodoxy created numerous print commissions that could be exploited into attractive monopolies, such as the new liturgical books printed in the wake of

13 Cyndia Susan Clegg, 'The Authority and Subversiveness of Print in Early Modern Europe', in Howsam (ed.), The Cambridge Companion to the History of the Book, pp. 125-142. 
the Council of Trent. ${ }^{14}$ The print industry itself, it is important to stress, was not necessarily opposed to control, and even actively sought government protection and approval. Printers, publishers and authors petitioned authorities for privileges to print particular works. ${ }^{15}$ Privileges were a way of protecting printers' investments against competitors, an impulse towards self-regulation motivated by the needs of individual printing businesses. ${ }^{16}$ This book therefore shifts the focus from attempts of authorities to police printing to study how those in power used the medium of print.

Scholars of early modern political communication have problematized the Habermasian opposition between a premodern representative public sphere, tightly controlled by homogeneous elites, and a modern, open, bourgeois public sphere. ${ }^{17}$ Their work has shown that neither ideal state was ever attained, and that there has always been an interaction between centres of political and religious power and the market of print. For the Holy Roman Empire, Volker Bauer has argued that books published by the elite for the elite trickled down, eventually opening up space for debating court life outside the society of princes. ${ }^{18}$ For England, Jason Peacey has shown that the pamphlet debates in

14 Jesús Martínez De Bujanda (ed.), Index des livres interdits (11 vols., Sherbrooke: Centre d'études de la Renaissance, 1984-2016); Paul F. Grendler, The Roman Inquisition and the Venetian Press (Princeton: Princeton University Press, 1977), pp. 170-174; Natalia Nowakowska, 'From Strassburg to Trent: Bishops, Printing and Liturgical Reform in the Fifteenth Century', Past and Present, 213 (2011), pp. 25-31; Robert M. Kingdon, 'The Plantin Breviaries: A Case Study in the Sixteenth-century Business Operations of a Publishing House', Bibliothèque d'Humanisme et Renaissance, 22 (1960), pp. 133-5o.

15 On the early development of printing privileges: Elizabeth Armstrong, Before Copyright: The French Book-Privilege System, 1486-1526 (Cambridge: Cambridge University Press, 1990); Joanna Kostylo, 'From Gunpowder to Print: The Common Origins of Copyright and Patent' in Martin Kretschmer, Lionel Bently, and Ronan Deasley (eds.), Privilege and Property: Essays on the History of Copyright (Cambridge: Open Book Publishers, 2010), pp. 21-5o; Christophre L.C.E. Witcombe, Copyright in the Renaissance: Prints and Privilegio in Sixteenth-Century Venice and Rome (Leiden: Brill, 2004).

16 See parts I and II of this volume, Shanti Graheli (ed.), Buying and Selling: The Business of Books in Early Modern Europe (Leiden: Brill, 2019) and Jane McLeod, Licensing Loyalty: Printers, Patrons and the State in Early Modern France (University Park: Pennsylvania State University Press, 2011).

17 See Rudolph Schlögl, 'Politik beobachten: Öffentlichkeit und Medien in der Frühen Neuzeit', Zeitschrift für Historische Forschung, 35 (2008), pp. 581-616; Patrick Boucheron and Nicholas Offenstadt (eds.), L'espace public au Moyen Âge. Débats autour du Jürgen Habermas (Paris: Presses Universitaires de France, 2011) and the contributions in Massimo Rospocher (ed.), Beyond the Public Sphere: Opinions, Publics, Spaces in Early Modern Europe (Bologna: Annali dell'Istituto storico italo-germanico in Trento, 2012).

18 Volker Bauer, 'Strukturwandel der höfischen Öffentlichkeit: Zur Medialisierung des Hoflebens vom 16. bis zum 18. Jahrhundert', Zeitschrift für Historische Forschung, 38:4 
the mid-century civil wars (previously perceived as an expression of public debate on the supposed free market of print) were, to a considerable extent, the result of the activities of politicians and their dependents. ${ }^{19}$ Similar arguments have recently been made against the presumed "discussion culture" of the Dutch Republic, which was more susceptible to control than has often been assumed..$^{20}$ Many of the debates on the assumed free market of print, then, were battles between conflicting authorities that ceased as soon as their conflict had been settled. Yet while they may have aspired to total control, none of these authorities could claim it when it mattered most. In a patchworked Europe where power was divided between numerous institutions, the interactions between print and power were many and diverse. The degree of control authorities were able to wield over the new medium differed from locality to locality, and was always dependent on neighbouring polities.

Based on the recent history of print dealing with aspects of the complex relationship between print and power in early modern Europe, we distinguish three focal points in terms of both research questions and methodology that permeate the chapters below. First is a focus on the agency of elites and authorities in the circulation and management of print. Each of the following chapters demonstrates an awareness of the sophistication with which early modern elites were able to shape debate and behaviour through patronage and active intervention, without ever attaining the hegemony implied in Habermas's shorthand concept of a representative public sphere. Jan Hillgärtner's chapter serves as a case in point. Dealing with what is perhaps the most prominent symbol of the rise of the public sphere, the printed newspaper, Hillgärtner shows that in the seventeenth-century Holy Roman Empire some newspapers were decidely instruments of power, whose existence relied on the approval,

(2011), pp. 585-620 and Volker Bauer, 'Buchmarkt, Hofpublizistik, Interaktion: Höfischer Mediengebrauch und Medienwechsel im Alten Reich - mit einem Seitenblick auf Sachsen-Gotha', Daphnis, 42:2(2013), pp. 571-594. See also Helmer Helmers, 'Public Diplomacy in Early Modern Europe. Towards a New History of News', Media History, 22:3-4 (2016), pp. 401-420.

19 Jason Peacey, Politicians and Pamphleteers: Propaganda During the English Civil Wars and Interregnum (Aldershot: Ashgate, 2004).

20 For the concept of "discussion culture" see Willem Frijhoff and Marijke Spies, Dutch Culture in European Perspective. 1650: Hard-won Unity (Assen: Van Gorcum, 2004). For a more in-depth analysis of the interactions between politicians, authors and booksellers see Roeland Harms, Pamfletten en publieke opinie. Massamedia in de zeventiende eeuw (Amsterdam: Amsterdam University Press, 2011). For a recent overview on the topic consult Helmer Helmers, 'Popular Participation and Public Debate', in Helmer Helmers and Geert Janssen (eds.), The Cambridge Companion to the Dutch Golden Age (Cambridge: Cambridge University Press, 2018), pp. 124-146. 
patronage, and even initiative of local rulers. Government print, which is at the forefront of recent book historical studies of the early modern period, is a central concern in various chapters. ${ }^{21}$

Secondly, a reassessment of the relationship between print and power requires a balanced treatment of orthodox and subversive content. While dissent and conflict by their nature command historical attention, it is vital to also analyse how print served the needs of orthodoxy and the status quo, which was arguably its more common role. It is for this reason that this volume, following recent book historical research, devotes much attention to the Catholic world of print. The later remarkable historical success of Protestant uses of print, for instance during the Revolt in the Low Countries or the Thirty Years' War, carries the risk of overemphasing the importance of Protestant print culture to the detriment of Catholic printing, especially in Southern and Eastern Europe. ${ }^{22}$ Catholic propaganda could be virulent too, and has started to receive its fair share of scholarship in recent decades, especially in the context of the French Wars of Religion. ${ }^{23}$

21 Several contributions to Andrew Pettegree (ed.), Broadsheets: Single-Sheet Publishing in the First Age of Print (Leiden: Brill, 2017) explore the topic of "official print" in terms of local and national governmental use of single-sheet printed documents. See also Arthur der Weduwen, Selling the Republican Ideal. State Communication in the Dutch Golden Age (University of St Andrews, Unpublished PhD dissertation, 2018) and Saskia Limbach, Government Use of Print. Official Publications in the Holy Roman Empire, 1500-1600 (Frankfurt: Klostermann Verlag, forthcoming).

22 Munck, Conflict and Enlightenment, is the most ambitious and wide-ranging recent book on print displaying a blind spot for Catholic Europe outside of France. While statistical data from the USTC bears out the very real concentration of print production in Northern Europe (accelerating in the mid-to late sixteenth-century), this greater output does not justify inattention to more peripheral print cultures. For the Thirty Years War, see e.g. Esther-Beate Körber, 'Der Dreißigjährige Krieg als europäisches Medienereignis' Europäische Geschichte Online (2015); Esther-Beate Körber, 'Deutschsprachige Flugschriften des Dreißigjährigen Krieges 1618 bis 1629', Jahrbuch für Kommunikationsgeschichte, 3 (2001), pp. 1-47; Pärtel Piiramäe, 'Just War in Theory and Practice: The Legitimation of Swedish Intervention in the Thirty Years' War,' The History Journal, 45:3 (2002), pp. 499-523; Sylvia Serena Tschopp, Heilsgeschichtliche Deutungsmuster in der Publizistik des Dreißigjährigen Krieges. Pro- und antischwedische Propagandain Deutschland 1628 bis 1635 (Frankfurt: Peter Lang, 1991); Peer Schmidt, Spanische Universalmonarchie oder "teutsche Libertet": das spanische Imperium in der Propaganda des Dreißigjährigen Krieges (Stuttgart: Franz Steiner Verlag, 2001). For the Revolt in the Low Countries, see n. 6.

23 Luc Racaut, Hatred in Print: Catholic Propaganda and Protestant Identity during the French Wars of Religion (Aldershot: Ashgate, 2002); Alexander Wilkinson, Mary Queen of Scots and French Public Opinion 1542-1600 (London: Palgrave, 2004). 
In the Eisensteinian paradigm, the Catholic Church's attitude towards print is mainly repressive and equated with the Index. It cut printers off from lucrative markets, such as printing of vernacular bibles and stifling scientific progress. ${ }^{24}$ Rome's engagement with the new printing technology, however, went far beyond prohibiting and censoring. In her contribution, Margaret Meserve demonstrates that the papacy under Pope Julius II was just as innovative in its use of the printing press as his Protestant opponents. Rather than the medium, the conservative papal message was the problem. Because they reiterated papal supremacy, Meserve argues, the many papal documents that were printed across Europe failed to resonate with the faithful. The medium itself was neither Protestant nor Catholic, and indifferent to change. While the Protestant Reformation is far from absent in this volume, contributions such as Meserve's, we hope, will stimulate the growing body of work on Catholic printing, much of which has appeared in recent contributions to this series. ${ }^{25}$

Finally, and arguably most importantly, researching the relationship between print and power also entails a turn to the archive, which has transformed recent scholarship of print. ${ }^{26}$ Scholars who have privileged the enlightening aspects of print relied predominantly on established collections of historical print: the books stored in university libraries, the collections of pamphlets and broadsheets compiled in nineteenth and early twentieth century catalogues, or the graphic prints disclosed, selected and studied by art historians. For generations of print historians, these collections were the mainstay research diet, made up of types of print that were both easily accessible and whose value was determined by their content. Indeed, very often these collections were built from books with content that met specific aesthetic or ideological criteria in the first place. It is the great achievement of recent work, including, most recently, Andrew Pettegree's and Arthur der Weduwen's The Bookshop of the World, that it added a broad range of ephemeral materials gleaned from the archives

24 Eistenstein, The Printing Press as an Agent of Change, pp. 415-421, pp. 648-659. Adrian Johns writes that Eisenstein asserts that 'censorship created a sweeping asymmetry in European print culture', see 'How to Acknowledge a Revolution', pp. 119-120. He argues we have to examine restrictions on a local level.

25 Alexander Wilkinson and Alejandra Ulla Lorenzo (eds.), A Maturing Market: The Iberian Book World in the First Half of the Seventeenth Century (Leiden: Brill, 2017); Natalia Maillard Álvarez (ed.), Books in the Catholic World during the Early Modern Period (Leiden: Brill, 2013); Benito Rial Costas (ed.), Print Culture and Peripheries in Early Modern Europe: A Contribution to the History of Printing and the Book Trade in Small European and Spanish Cities (Leiden: Brill, 2012).

26 Kate Peters, Alexandra Walsham, and Liesbeth Corens (eds.) Archives and Information in the Early Modern World (Oxford: Oxford University Press, 2018); Elizabeth Yale, 'The History of Archives: The State of the Discipline', Book History, 18 (2015), pp. 332-359. 
to broad discussions of print culture. ${ }^{27}$ Various chapters in this volume, too, are the result of painstaking research into overlooked kinds of print (such as contracts, forms, placards, advertisements, and printed newspapers) with extremely low survival rates, typically conserved in archives rather than libraries. Forrest Strickland, for instance, uses his systematic survey of a dispersed body of seventeenth-century printed auction catalogues to analyse the libraries of Dutch reformed ministers as sources of authority.

It was exactly the unglamorous and dispersed kinds of print, underwhelming in form and uniform in content, that could carry great force. The archival turn in the history of print has opened new possibilities to analyse the interactions between governments, printing and printers in early modern Europe. As early modern authorities explored the potential of printed forms of all kinds, the book industry thrived: it was the steady stream of government jobs, after all, that provided reliable profits. It should be no surprise, then, that the rise of the paper and print industries ran parallel to the remarkable expansion of new bureaucracies in this period. ${ }^{28}$

Besides enabling the study of overlooked types of print, the turn to the archive is also indispensable when we seek to study agency. For as Jason Peacey, has emphasized, print collections do not only provide us with a distorted image of the kinds of print that circulated in early modern society, they also obscure the power mechanisms behind their circulation, the workings of the public sphere in general. ${ }^{29} \mathrm{~A}$ focus on these collections creates the false impression of a free market for print that was unconstrained by power and patronage. Archival research, he argues, problematises the notion of a free market of print, at least in the sixteenth and seventeenth centuries. Many of the anonymous persuasive texts, the news, rumours, songs and libels that aimed to shape opinion in early modern Europe may seem to be part of a popular culture of dissent, to originate in communities, and to circulate on

27 Andrew Pettegree and Arthur der Weduwen, The Bookshop of the World. Making and Trading Books in the Dutch Golden Age (Yale: Yale University Press, 2019); See also: Flavia Bruni and Andrew Pettegree (eds.), Lost Books: Reconstructing the Print World of Pre-Industrial Europe (Leiden: Brill, 2016).

28 Randolph Head, Making Archives in Early Modern Europe: Proof, Information and Political Recordkeeping, 1400-1700 (Cambridge: Cambridge University Press, 2019); E.C. Dijkhof etc. (eds.) Medieval documents as artefacts. Interdisciplinary perspectives on codicology, palaeography and diplomatics (Hilversum: Verloren, 2020); Megan Williams, 'Unfolding Diplomatic Paper and Paper Practices in Early Modern Chancellery Archives', in Arndt Brenecke (ed.), Praktiken der Frühen Neuzeit. Akteure, Handlungen, Artefakte (Cologne: Böhlau Verlag, 2015), pp. 496-508.

29 Jason Peacey, 'Print and Public Politics in Seventeenth-Century England', History Compass, 5:1 (2007), pp. 85-111. 
the free market. In reality, however, their creation and dissemination was often carefully tailored and managed by those in power. ${ }^{30}$ Rindert Jagersma's chapter exemplifies the sophistication with which elites managed their publicity campaigns while seeking to obscure their own involvement. On the eve of the Glorious Revolution in 1688, Jagersma shows, the Dutch stadtholder William III deliberately resorted to censorship of his own propaganda, both to conceal his involvement in the publication of a notorious pamphlet slandering the King of England and to draw extra attention to it. Jagersma's approach shows that only archival research can lead us to identify the figures who initiated, supported, financed or restrained the production of information and their aims. Only such an archival approach can lead to a better understanding of the mechanisms and mentalities that governed the relationship between print and power.

\section{Types of Print, Types of Power}

New media are often credited with great power. Printing, in the early modern period, was no exception. The deep involvement of early modern government and church officials in the production, circulation, and censorship of print indicates how apprehensive they were of its effects. Like modern new media, printed texts were often likened to infectious diseases, which could spread and poison the body of the state or the church if left uncontested, or to weapons more powerful than those made from steel. ${ }^{31}$ Early modern rulers were extremely sensitive to the slightest hint of dissension, disrespect or unorthodoxy in printed texts, as any crack in the facade of authority and uniformity might lead to its collapse. The fierce propaganda wars and censorship efforts in early modern Europe, however flawed, were the result of a deep belief in the affective power of print.

One of the driving forces behind this belief was the fear of conversion in post-Reformation Europe. The success of the Reformation had shown how rapidly religious conversion could undermine institutional powers that were previously taken for granted. In contrast to interfaith conversion between, for instance, Islam and Christianity, interconfessional conversion was an insidious

30 For a similar point, applied to international rather than English politics see Helmers, 'Public Diplomacy in Early Modern Europe', pp. 401-420.

31 On the metaphor of print as poisonous or infectious, see Helmer Helmers, 'Illness as Metaphor: The Sick Body Politic and Its Cures', in Jaap Grave, Rick Honings and Bettina Noak (eds.), Illness and Literature in the Early Modern Low Countries (Göttingen: Vandenhoeck and Ruprecht, 2015), pp. 97-120. 
and ever-present threat to communities. These were brought about by proselytisers who relied not only on the power of speech, but also on printed books. Indeed, not infrequently, crypto-Protestants or crypto-Catholics could only be discovered by such books, hidden on attics or beneath floorboards. As a result, conversion literature proliferated in early modern Europe, sometimes expressing the anxiety of religious communities about being undermined by unseen enemies, and sometimes displaying the power and confidence of one or the other confession. ${ }^{32}$ Conversion récits, for example, were an important feature of French print culture in the seventeenth century. ${ }^{33}$ Martin Christ's chapter offers an analysis of the growth and development of Revocationspredigt, or revocation sermon, a genre that has been under-studied in a German context. Christ shows how public displays of an individual preacher's conversion were an important part of the violent history of Catholic-Lutheran conflict in the seventeenth century.

In this confessional battle, images were considered to be especially powerful. While traditional scholarship pitted an iconoclastic Protestantism of the Word against the profusely visual culture of the Catholic Baroque, recent work has told a more complex story, and analyses the negotiation and appropriation of imagery as it travelled across confessional borders. ${ }^{34}$ Protestant piety, on this account, led to different uses and forms of the visual and the theatrical, rather than being altogether hostile to it. Nora Epstein's chapter, investigating

32 See David M. Luebke etc. (eds.), Conversion and the Politics of Religion in Early Modern Germany (New York/Oxford: Berghahn, 2012); Sarah Rütter, Konstruktion von Bekenntnisidentität in Konversionsschriften der Frühen Neuzeit (Berlin: LIT Verlag, 2014); Abigail Shinn, Conversion Narratives in Early Modern England. Tales of Tuning (London: Palgrave, 2018); Lieke Stelling Religious Conversion in Early Modern English Drama (Cambridge: Cambridge University Press, 2019). See also: Andrew Pettegree, Reformation and the Culture of Persuasion (Cambridge: Cambridge University Press, 2005).

33 Karin Maag, 'Seventeenth Century French Conversion Narratives: Making Sense of Shifting Confessional Allegiances', in Jon Balserrak and Richard Snoddy (eds.), Learning from the Past: Essays on Reception, Catholicity, and Dialogue in Honour of Anthony N.S. Lane (London and New York: Bloomsbury T \& T Clark, 2015), pp. 93-106; Keith P. Luria, Sacred Boundaries: Religious Coexistence and Conflict in Early-Modern France (Washington: The Catholic University of America Press, 2005), pp. 248-307; Thierry Wanegffelen, 'Récits de conversion des XVI ${ }^{\mathrm{e}}$ et $\mathrm{XVII}{ }^{\mathrm{e}}$ siècles: Discours confessionel et expérience individuelle', in Jean-Christophe Attias (ed.), De la conversion (Paris: Editions du Cerf, 1998), pp. 183-202; Roger Duchene (ed.), La conversion au XVII e siècle, Actes du XII e colloque de Marseille (janvier 1982) (Marseille: Centre Méridional de Rencontres sur le XVII ${ }^{\mathrm{e}}$ siècle, 1983).

34 See Bridget Heal, 'Introduction: Art and Religious Reform in Early Modern Europe', Art History. Special issue on Religious Reform in Early Modern Europe, 40:2 (2017), pp. 246-255 and Els Stronks, Negotiating Differences. Word, Image and Religion in the Dutch Republic (Leiden: Brill, 2011). 
how the London printer John Day and his son appropriated imagery from Catholic Books of Hours in their Protestant prayer books, is in keeping with this recent reappraisal of the role of religious imagery in early modernity. In Ramon Voges's chapter on the Hogenberg prints of the Dutch Revolt, the power of the image in early modern religious conflict comes into play in a different way. While Hogenberg's famous newsprint-like images have often been seen and used as more or less neutral illustrations of historical events, Voges argues that they should be treated as historical powers themselves, which were able to shape both the history and the history-writing of the prolonged religious warfare in the Low Countries.

If printed sheets of paper were ever literal embodiments of power, it was in the field of law. As early modern authorities increasingly turned to print for promulgating and storing their laws and regulations, reinforcing traditional methods of manuscript and oral dissemination, print regulated first civic and later rural everyday life. Renaud Adam's chapter does much to reinforce this argument. Investigating the evolving relationship between the Burgundian and Habsburg authorities in the Low Countries and the printing industry (a relationship hitherto remarkably unstudied) Adam probes the socio-economic consequences of printing the law. Highlighting the entanglement between the history of the book and the history of state formation, he represents a growing group of scholars of print and communication who seek to reincorporate the history of law, which has suffered much neglect due to the cultural turn in early modern scholarship, into mainstream historiography. ${ }^{35}$

Adam's chapter alerts us to the fact that urbanised regions such as the Low Countries and the Italian States were leading in the application of print for government uses. ${ }^{36}$ Focusing on a conflict in seventeenth-century Groningen, in the Northern Netherlands, Arthur der Weduwen's chapter shows how, in

35 Leslie Moran, 'Legal Studies after the Cultural Turn: A Case Study of Judicial Research', in Sasha Roseneil and Stephen Frosh (eds.), Social Studies after the Cultural Turn (London: Palgrave, 2012), pp. 124-143; Mark Somos, 'The Unseen History of International Law: A Census Bibliography of Hugo Grotius's De iure belli ac pacis', Grotiana, 40 (2019), pp. 173179; Nicholas Simon, 'Une culture d'État? Législation et prise de décision dans les Pays-Bas espagnols (1580-1610)', in Eric Bousmar, Philippe Desmette and Nicholas Simon (eds.), Légiférer, gouverner et juger. Mélanges d'histoire du droit et des institutions (IX ${ }^{e}-X X I^{e}$ siècle) offerts à Jean-Marie Cauchies à l'occasion de ses 65 ans (Brussels: Presses de l'Université Saint-Louis, 2016), pp. 295-308; Paul Raffield and John Morrill, Images and Cultures of Law in Early Modern England: Justice and Political Power, 1558-1660 (Cambridge: Cambridge University Press, 2004).

36 See contribution in Pettegree (ed.), Single-Sheet Publishing as well as Frances Maguire, Bonds of Print and Chains of Paper: Rethinking Print Culture and Social Formation in Early Modern England, c.1550-c.170o. (University of York, Unpublished PhD dissertation, 2017). 
a remarkable conflict, competing authorities employed state publications to win over the urban community. Though prolific in their use of print, civic authorities in the Low Countries were hardly unique in their efforts to use the new medium for governing their growing polities. Rachel Midura and Gautier Mingous trace how the local authorities of late-sixteenth-century Milan and Lyon increasingly relied on print to regulate early modern city life. Mingous demonstrates that the city government of Lyon, one of the most important trading centres in Europe, was rather reluctant to spread information in print at first, but embraced it due to pressing circumstances. In the chapters of der Weduwen, Midura, and Mingous, religious and political conflict is shown to be a catalyst for increased government uses of print as they struggled to maintain the health of the civic body politic. The outbreak of disease, such as the plague in Northern Italy in 1576 , had similar effects in Milan and Lyon. ${ }^{37}$ Indeed, as Midura shows, both ailments of the body politic (plague and political conflict) were often entangled and provoked magistrates to experiment with the medicine of print.

As major and reliable customers, civic and state institutions provided stimulus for the printing industry also, or perhaps even especially, in more peripheral areas such as sixteenth-century England. Celyn Richards' chapter investigates how, under Edward VI, the introduction of Protestantism led to major commissions of canonical texts by the state, which sought to strengthen evangelicalism through print. Partly, Richard's analysis of the volume and economical value of these commissions conforms to the established association between Protestantism and print. However, it also departs from this narrative by showing that the Edwardian regime was an active and substantial participant in the print industry. Rather than being the result of a grassroots movement, Protestant print in sixteenth-century England was orchestrated from above, with major consequences for the economic viability of print.

In establishing the connections between authorities and print, we should, as a recent volume has it, look beyond the metropolis and the nation. ${ }^{38}$ If civic bureaucracies were early to adopt and manage a wide variety of print to enhance their grip on local societies, other levels of government operated on different timelines, different scales, and with different instruments. In the

37 For a recent discussion of print as an instrument of public health management, see Alexandra Bamji, 'Health passes, print and public health in early modern Europe', Social History of Medicine, 32:3 (2019), pp. 441-464.

38 James J. Connolly, Patrick Collier, Frank Felsenstein, Kenneth R. Hall and Robert G. Hall (eds.), Print Culture Histories Beyond the Metropolis (Toronto: Toronto University Press, 2016). Also see various contributions in edited volume by Costas (eds.), Print Culture and Peripheries in Early Modern Europe. 
Austrian countryside, where the old aristocracy still reigned over sparsely populated mountainous territory, bureaucratic print penetrated much later and slower than in major political and commercial cities such Milan or Lyon. Andreas Golob's chapter analyses the ways in which officials in Enlightenment Austria used print to reform the administration. As a whole, this volume demonstrates the realisation among scholars that we cannot understand the changing relationship between print and power as long as we limit ourselves to studying a single tier of authority, be it from a local, national, or international perspective.

Early modern authorities ordered many kinds of print, thus providing a crucial, steady stream of commissions for printers, but they were also vital for the industry by acting as patrons for printers in the early modern sense of the word. In her chapter on the Polish-Lithuanian printer Jan Januszowski in Krakow, Justyna Kiliańczyk-Zięba shows the importance of church and government patronage for this prominent sixteenth-century printing house. While the government jobs discussed by Der Weduwen, Mingous, Richards and Golob meant easy profit for printers, Kiliańczyk's focus on commission from Polish prelates communicates a more complicated story. Her chapter shows the risks, difficulties and anxieties that came with prestigious but unreliable patronage, and the constant and humbling networking it required.

Having the right connections to powerful individuals within papal curia was also crucial for any printer active in Rome in the first half of the sixteenth century. In reconstructing the creation of a new papal office, the stampatore camerale, Paolo Sachet demonstrates the harsh competition between printers for the support of powerful Cardinals, who might entrust them with the printing of papal documents. In this ever-changing environment, printers needed to maneuver carefully. Yet despite the difficulties early modern printers had in navigating perilous powerscapes, the rewards for those who persevered could outweigh these troubles. Thus, after twenty years of labour, the Roman printer Antonio Blado and his family finally obtained the lucrative privilege to print papal bulls, briefs and promulgations. In Krakow, Januszowski was eventually even elevated into the Polish-Lithuanian nobility. This was a rare feat for an early modern printer, and had only been possible through his relentless efforts to please the powers that be with his prestigious projects.

Prestige was one of the main currencies connecting the realms of print and power. Elite patrons could raise the renown and profit of a printer, while the printer contributed to the reputation of the patron. Honour was also very much at stake for Cardinal Ferdinando de' Medici, who founded the extraordinary printing house Typographia Medicea (which specialised in Arabic and Syriac type) in Rome in 1584. Caren Reimann's chapter on Ferdinando's patronage 
shows that he remained very involved with the business even after leaving Rome and becoming Grand Duke of Tuscany. In contrast to Januszowski's patrons, who quickly lost interest in his ventures, Ferdinando de' Medici saw how a press could be an instrument to further his political goals. His case allows Reimann to investigate the boundaries between international cultural politics, religion, economy and the print market. In this case too, the support of power was indispensable for a profitable enterprise. Once the Grand Duke stepped back from the Typographia, its director, Raimondi, struggled for survival. Part of the unhelpfulness of a concept like the representative public sphere lies in the fact that it cannot grasp the complex and continually changing relationships between printers, patrons and the international market.

Competition between elites and, therefore, between patrons, was an important factor in advancing both the print market and ideological debates more broadly, both within and between territories. Aristocratic households and embassies deserve a special mention in this regard, as privileged spaces. These were free havens that could create room for experiment or for the dissemination of illicit, even subversive literature. Chelsea Reutcke's chapter discusses the spectacular example of the household of the Queen of England, Catherine of Braganza, which functioned as a "grey area" within her own husband's religious and censorship laws, and became a centre of illicit Catholic publication. Similarly, Ernesto Oyarbide discusses the case of the notorious Spanish ambassador to the court of James I, Diego Sarmiento de Acuña, Count of Gondomar, whose protection of Catholics in England also extended to print. For both Queen Catherine and for Gondomar, this involved stimulating international exchange that would otherwise have been barred. Once we realise that their cases exemplify many other powerful patrons acting against states aiming at uniformity, we can understand the Herculean task of early modern censors and custom officers, whose most formidable opponents were shielded by diplomatic immunity. Even in the age of absolutism, international competition between elites thus helped to ensure a diverse media landscape.

\section{Printing for Power}

Printing for power meant much more than the political polemic that has attracted so much scholarly attention. Frequently, print that acted in the service of power was an inconspicuous, ordinary part of early modern life, like the printed documents that city governments used to streamline their functioning. In this way, print also helped to communicate the symbols of power, like official seals. These had applications beyond bureaucracy, and could just as easily 
be directed to enforce a law as they could be used to add the weight of authority to a propaganda campaign. Beyond these very clear-cut examples where the symbols of power literally appeared on the printed page, the influence of individual patrons and competing authorities added a variety of formats and funds to what we might consider printing for power. The same government and church-sanctioned print runs that helped disseminate the rhetoric, ideology, aesthetics or literal decrees of power created lucrative opportunities for the printers who could secure rights to them.

Whereas Marchand's frontispiece and Eisenstein monumental book present print as an impersonal force of enlightened progress, this volume adopts a less idealistic view of the new medium. By asking how print served the needs of those in power, and by closely examining the roles of patronage, control, and orthodoxy in the early modern print world, a counter-narrative to the Enlightenment narrative starts to form in which print's role in early modern society is more accurately described as that of an agent of power rather than of change. Print thrived by serving the needs of the powerful, and in that service it was fully capable of stifling change rather than promoting it. Elite patronage in the print world conferred economic and legal protections that could make or break the fortunes of a printing house. Printers courted wealthy patrons both institutional and individual, and authorities sought to harness the persuasive and productive capacities of print. This not to say that print was fully controlled by homogeneous elites, of course, but rather to serve as a reminder that political and religious interests were a dominant force on the market of print, and it requires careful, contextualized research to assess their role. If change occurred, and it obviously did, this was not necessarily the result of the medium itself, but of the competition between elites seeking to use the power of print for their own good. 